\title{
Peningkatan ketahanan suhu dingin kulit atasan sepatu melalui pengurangan daya penyerapan air dan pengaruhnya terhadap sifat fisik dan morfologi
}

\section{Increasing cold resistance of upper leather by reducing its water absorption ability and the effects on the physhical properties and morphology}

\author{
Prayitno*, Emiliana Kasmudjiastuti \\ Balai Besar Kulit, Karet, dan Plastik, Jl. Sokonandi No. 9 Yogyakarta 55166, Indonesia \\ *Penulis korespondensi. Telp: +62 274 512929, 563939; Fax: +62 274563655 \\ E-mail: prayitnobbkkp@yahoo.com
}

Diterima: 16 September 2016 Direvisi: 17 Mei 2017 Disetujui: 18 Mei 2017

\begin{abstract}
A research has been undertaken to increase the cold resistance of upper leather by decreasing its water absorption ability. Fluorinated acrylic polymer, a water repellent substance, was added at fatliquoring and finishing stages of upper leather with different concentrations levels. Research findings showed that an increase in the water-repellent concentration, i.e. by $5 ; 7.5 ; 10 ; 12.5$; and 15\%, result in increases in tensile strength, tearing strength, and elongation at break, whereas decreases in water absorption ability. No significant differences for the other physical properties such as water vapor absorption, water vapor permeability, and flexing resistance and they met the standard for shoe leather. Results of scanning electron microscopy indicated an increased thin layer of water repellent on leather fibers as the water-repellent concentration increased. The leather fibers looked smoother, glistened, and thicker. This indicates the penetration of water repellent onto leather fibers.
\end{abstract}

Keywords: water absorption, water repellent, cold resistance, upper leather.

\begin{abstract}
ABSTRAK
Penelitian telah dilakukan untuk meningkatkan ketahanan terhadap suhu dingin kulit atasan sepatu dengan menurunkan daya serap airnya. Penelitian dilakukan dengan menambahkan suatu bahan water repellent jenis fluorinated acrylic polymer pada tahapan peminyakan dan finishing kulit atasan sepatu dengan konsentrasi yang divariasi. Hasil penelitian menunjukkan, kenaikan konsentrasi water repellent $5 ; 7,5 ; 10 ; 12,5 ;$ dan $15 \%$ menaikkan kuat tarik, kuat sobek dan kemuluran, sedangkan daya serap air menurun. Sifat fisis penyerapan uap air dan permeabilitas uap air, dan ketahanan bengkuk tidak menunjukan perbedaan nyata dan memenuhi standar kulit sepatu. Hasil scaning electron microscopy (SEM) menunjukan bertambahnya lapisan tipis dari water repellent pada serabut kulit dengan meningkatnya konsentrasi water repellent. Serabut kulit terlihat lebih halus, mengkilat, dan berisi. Hal tersebut menunjukan adanya penetrasi water repellent pada serabut kulit.
\end{abstract}

Kata kunci: penyerapan air, water repellent, ketahanan dingin, kulit atasan.

\section{PENDAHULUAN}

Ketahanan air dari kulit tersamak merupakan salah satu sifat yang sangat penting untuk berbagai penggunaan produk dari kulit, seperti alas kaki dan jaket yang menuntut kenyamanan dalam pemakaiannya baik dalam keadaan basah maupun dingin. Kulit yang menyerap banyak air akan kehilangan sifatnya dalam mengisolasi panas mau- pun dingin. Kulit atasan sepatu disyaratkan penyerapan air tidak melebihi 25-30\% (Jankauskaitè et al., 2012). Selain harus memenuhi batas penyerapan air, menurut Śmiechowski et al. (2014) atasan sepatu dituntut pula untuk kemampuannya dalam permeabilitas uap air (water vapor permeability) dan kemampuannya menyerap uap air (water vapor absorption). 
Kulit atasan sepatu tahan dingin harus tahan air (waterproofing) untuk dapat menahan pengkerutan karena suhu dingin agar kulit tidak pecah, namun tetap memenuhi persyaratan water vapor permeability (WVP) dan water vapor absorption (WVA). Hal tersebut sangat bergantung pada teknis proses penyamakan terutama pada proses retanning, fatliquoring, dan finishing (Sharphouse, 1989).

Kulit mentah tersusun terutama dari protein kolagen dimana protein ini berpotensi untuk dilakukan modifikasi, salah satunya dengan mengubah sifat-sifat asam amino dari kolagen yang mudah mengalami pembusukan menjadi kulit samak yang tidak mengalami pembusukan. Covington (2009) menyebutkan ada sekitar 18 jenis asam amino yang masing-masing mempunyai rantai samping yang berbeda dalam struktur kolagen yang berperan dalam proses penyamakan, misal serin, sisteina, dan sistina berturut-turut dengan rantai samping $-\mathrm{CH}_{2} \mathrm{OH},-\mathrm{CH}_{2} \mathrm{SH}$, dan $-\mathrm{CH}_{2} \mathrm{SSCH}_{2}-$ yang berpengaruh penting pada proses penghilangan bulu. Menurut Sarkar (1995) pada jaringan kolagen banyak dijumpai gugus-gugus polar fungsional seperti -OH, - $\mathrm{COOH},-\mathrm{C}_{2} \mathrm{H}_{4} \mathrm{OH}$; -SH; -S-S; $-\mathrm{CH}_{2}-\mathrm{NH}_{2}$, dan $-\mathrm{CONH}-$, juga gugus non polar meliputi $-\mathrm{CH}_{3},-\mathrm{CH}\left(\mathrm{CH}_{3}\right)_{2},-\mathrm{CH}_{2}$, dan $-\mathrm{C}_{6} \mathrm{H}_{5}$.

Kebanyakan bahan-bahan yang digunakan dalam proses penyamakan pada umumnya bersifat hidrofilik, yang mempunyai afinitas yang baik dengan air, sehingga sifat penyerapan air kulit samak yang dihasilkan besar. Oleh karena itu untuk meningkatkan ketahanan terhadap penyerapan air kulit tersamak, dapat ditempuh dengan beberapa cara baik pada tahapan proses maupun pada finishing dengan memodifikasi pada permukaan kulitnya.

Serenko et al. (2014) menyatakan untuk memproduksi kulit atasan sepatu dengan sifat $w a-$ terproof dapat ditempuh dengan memberikan pelapisan tipis bahan polimer tertentu pada permukaan kulit atau dengan senyawa yang mengandung partikel nano pada proses finishing. Namun menurut Kanagy and Vickers (1950), penggunaan bahan untuk peningkatan ketahanan terhadap penyerapan air berakibat menurunkan sifat WVP yang merupakan salah satu faktor keenakan pakai dari sepatu. Menurut Tang et al. (2013) ada beberapa faktor yang mempengaruhi WVP seperti ketebalan kulit, berat jenis, dan kemampuan kulit menyerap air. Untuk kemampuan penyerapan air, semakin besar kemampuan kulit menyerap air semakin besar sifat WVP-nya namun di sisi lain akan menurunkan ketahanan kulit terhadap suhu dingin. Untuk mendapatkan kulit samak dengan kemampuan menyerapan air maksimum 30\% (Jankauskaitè et al., 2012) dapat dilakukan dengan beberapa cara yaitu dengan sealing kulit pada proses finishing-nya menggunakan lapisan tidak tertembus air. Dapat juga dengan proses closed waterproofing yaitu dengan menutup rongga-rongga di antara jaringan kulit dengan bahan water repellent, atau dengan open waterproofing yaitu dengan membentuk suatu net hydrophobic di sekitar jaringan tanpa pengisi permukaan.

Pengurangan kemampuan penyerapan air dengan metode sealing kulit dilakukan pada proses finishing dengan sistem pelapisan (coating) pada permukaan kulit, dengan metode ini akan menutup juga seluruh pori kulit sehingga mengurangi kenyamanan pada produknya. Waterproofing dengan metode sealing pelapisannya hanya dilakukan pada bagian permukaan kulit (nerf), sehingga pada bagian dagingnya masih memungkinkan untuk dapat menyerap air. Pada closed waterproofing, pori-pori kulit juga akan tertutup menyebabkan tidak ada aliran udara yang menyebabkan produk sepatunya tidak nyaman digunakan. Metode open waterproofing akan memberikan sifat waterproofing kulit juga pori-pori kulit tidak tertutup sehingga masih dimungkinkan untuk aliran udara dalam kulit.

Untuk membuat kulit atasan sepatu agar tahan terhadap suhu dingin dapat dilakukan dengan pemilihan bahan retanning maupun bahan fatliquoring (Jankauskaite et al., 2014). Bahan penyamak dan retanning dari jenis nabati akan memberikan kemampuan menyerap air yang besar, sehingga tidak sesuai untuk membuat kulit tahan dingin (Prayitno et al., 2016). Menurut Shahat et al. (2010) bahan retanning derivat dari polimer akrilat dapat memberikan efek waterproofing. Proses peminyakan (fatliquoring) merupakan tahapan yang sangat penting pada proses pembuatan kulit atasan sepatu tahan dingin. Dengan proses ini dan rendahnya kandungan air dalam serat kulit diharapkan kulit akan tetap elastis dalam suhu rendah.

Penelitian ini bertujuan untuk meningkatkan ketahanan kulit terhadap suhu dingin dengan menurunkan daya serap air menggunakan bahan water repellent dari jenis fluorinated acrylic polymer. Bahan ini merupakan repellency air dan minyak yang sangat baik yang diharapkan dapat 
memperbaiki penyerapan air kulit atasan sepatu hasil penelitian oleh Jankauskaite et al. (2012) yang menggunakan water repellent jenis emulsified synthetic oil kombinasi dengan larutan dalam air acrylic acid dan ester copolymer yang menghasilkan penyerapan air sebesar $40 \%$.

\section{BAHAN DAN METODE \\ Bahan Penelitian}

Bahan penelitian yaitu kulit sapi wet blue, wetting agent (Mulgan BW), natrium formiat, krom sintan, natrium bikarbonat, neutralising syntan, resin akrilik, Tanicor SGN, Sincal MS, cat dasar, Derminol SBJ, Derminol SPE, anti jamur, asam formiat, fluorinated acrylic polymer, bahan finishing (RA2, RU3906, BI 372, FI11250, Penetrator, Pigmen), dan bahan untuk top coating (lak netral, thinner super, dan KS).

\section{Peralatan Penelitian}

Alat proses penyamakan meliputi drum penyamakan, alat pengetaman, alat pementangan, dan alat seterika, sedangkan untuk pengujian digunakan alat uji kuat tarik, kuat sobek dan kemuluran Zwick/Roell z020 tipe KAP-TC model 2007, penyerapan air, permeabilitas air dan uap air, dengan alat uji water permeability tester STM 473, alat uji flexing, dan scanning electron microscope (SEM) merek SNE $3200 \mathrm{M}$ untuk uji morfologi.

\section{Metode Penelitian}

Rancangan penelitian dalam percobaan ini disusun dengan sistem pola searah, terdiri atas lima taraf perlakuan konsentrasi water repellent dengan jenis bahan penyamak krom. Tiap taraf perlakuan mendapatkan tiga kali ulangan sehingga terdapat 15 unit percobaan dan tiap satuan pengamatan terdiri dari satu side kulit.

Pelaksanaan penelitian dilakukan dengan bahan penyamak krom dan digunakan water repellent yang divariasi 5,$0 ; 7,5 ; 10,0 ; 12,5$; dan $15 \%$. Hasil dianalisis untuk mengetahui jumlah water repellent yang dapat memberikan sifat-sifat kulit atasan yang waterproof dan tahan dingin. Proses penyamakan dilaksanakan sebagai berikut: bahan baku berupa kulit wet blue sapi, setelah dilakukan pembasahan ulang (wetting back) dan pencucian, dilakukan penetralan hingga $\mathrm{pH}=5$ menggunakan natrium formiat, soda kue, dan neutralizing syntan. Kemudian dilakukan penyamakan ulang dengan menggunakan bahan penyamak resin akrilik dan Tanicor SGN dilanjutkan dengan pengecatan dasar menggunakan cat dasar warna hitam dan penetrator Sincal MS. Proses peminyakan dengan bahan fatliquor Derminol SBJ, Dermenol SPE, dan anti jamur, setelah fiksasi dengan FA, ditambahkan water repellent jenis fuorinated acrylic polymer. Terakhir proses finishing dan top coating.

Pengujian analisis kimia dan fisika kulit atasan sepatu meliputi uji: penyerapan air, kekuatan tarik, kemuluran, kekuatan sobek, WVP, WVA, ketahanan bengkuk (ISO, 2007), dan morfologi.

\section{HASIL DAN PEMBAHASAN Penyerapan Air}

Hasil uji penyerapan air kulit atasan sepatu samak krom dengan penambahan water repellent disajikan pada Gambar 1. Dari grafik terlihat meningkatnya penggunaan water repellent akan menurunkan kemampuan absorpsi air dari kulit tersamak dengan bahan penyamak krom, sesuai dengan maksud penggunaan water repellent yang merupakan bahan yang bersifat hydrophobic yang melapisi serat kulit. Penyerapan air terendah terjadi pada penggunaan water repellent $12,5 \%$, yaitu sebesar $23,8 \%$, masih memenuhi persyaratan untuk kulit tahan dingin yakni 25\% (Jankauskaitè et

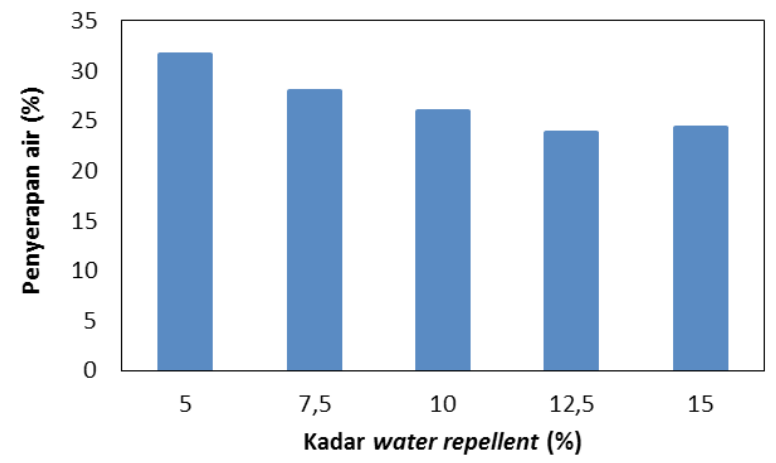

Gambar 1. Grafik kadar water repellent vs penyerapan air.

Tabel 1. Analisis sidik ragam penyerapan air.

\begin{tabular}{lccccr}
\hline Sumber keragaman & \multicolumn{1}{c}{ d.b } & \multicolumn{1}{c}{$\mathrm{SS}$} & $\mathrm{MS}$ & $\mathrm{F}_{\text {hit }}$ & $\mathrm{F}_{\mathrm{tbl}}$ \\
\hline Treatment & $(\mathrm{n}-1)=4$ & $\mathrm{SS}_{\mathrm{t}}=1208,90$ & $\mathrm{~S}_{\mathrm{t}}{ }^{2}=113,40$ & 1,50 & 3,48 \\
Error & $\mathrm{n}(\mathrm{k}-1)=10$ & $\mathrm{SS}_{\mathrm{e}}=755,30$ & $\mathrm{~S}_{\mathrm{p}}{ }^{2}=75,53$ & & \\
\hline
\end{tabular}




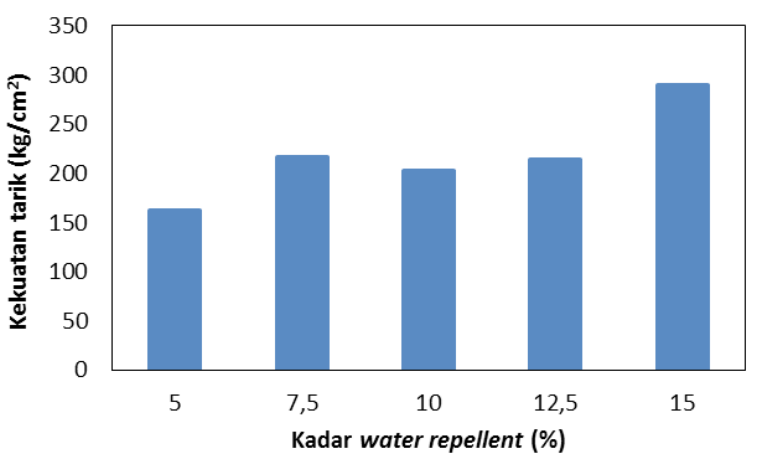

Gambar 2. Grafik kadar water repellent vs kekuatan tarik.

al., 2012), sedangkan penggunaan water repellent $5 \%$ memberikan kulit samak krom yang tinggi sebesar $31,58 \%$, tidak memenuhi persyaratan kulit atasan sepatu tahan dingin.

Hasil analisis sidik ragam dengan taraf kepercayaan $95 \%$ seperti disajikan pada Tabel 1. Diperoleh $\mathrm{F}_{\mathrm{ht}=1,50} \leq \mathrm{F}_{\mathrm{tbl}=3,48}$ menunjukkan adanya penurunan yang tidak berbeda nyata pada setiap perlakuan. Hal tersebut kemungkinan disebabkan sifat samak krom yang memberikan suhu kerut tinggi berarti tingkat kamatangan penyamakan tinggi sehingga afinitas serat terhadap air akan rendah.

\section{Kuat Tarik}

Uji kuat tarik kulit atasan sepatu tahan dingin hasil penelitian disajikan pada Gambar 2. Hasil menunjukan adanya kenaikan kuat tarik dari setiap kenaikan penambahan bahan water repellent. Hal tersebut kemungkinan disebabkan meningkatnya kadar water repellent selain akan menghambat penyerapan air juga sifat minyak dari water repellent akan meningkatkan keliatan serat-serat kulit sehingga kuat tariknya meningkat. Namun dari grafik terlihat bahwa terjadi inkonsistensi dalam kekuatan tarik pada kulit hasil penelitian dengan

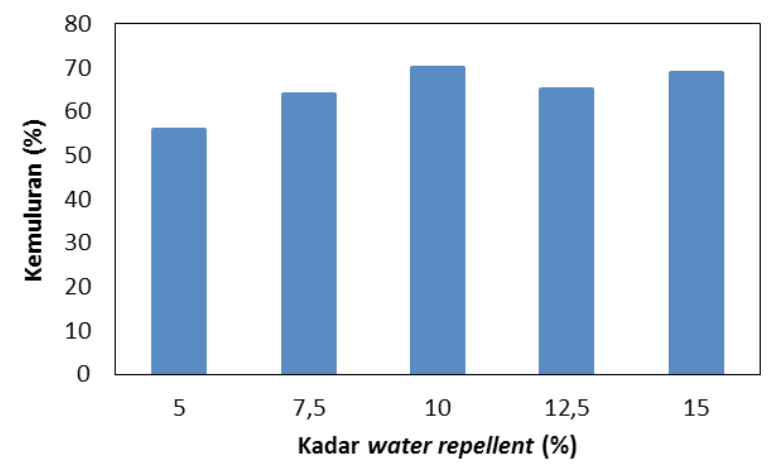

Gambar 3. Grafik kadar water repellent vs kemuluran.

penggunaan water repellent $7,5 \%$. Hal tersebut kemungkinan disebabkan tidak seragamnya mutu bahan baku kulit wet blue sehingga kuat tarik yang dihasilkan meninggi.

Hasil analisis sidik ragam untuk kuat tarik disajikan pada Tabel 2, terlihat dari bahwa $\mathrm{F}_{\text {hitung=1,33 }}$ lebih rendah dari $\mathrm{F}_{\text {table }=3.48}$, sehingga kadar water repellent tdak mempengaruhi sifat kuat tarik dari kulit jadi. Sifat fisika kulit jadi sangat ditentukan oleh jenis bahan penyamak yang digunakan. Samak krom saat ini merupakan bahan penyamak yang memberikan keunggulan dalam sifat fisika kulit.

\section{Kemuluran}

Hasil uji kemuluran disajikan pada Gambar 3 , dari grafik terlihat bahwa water repellent tidak memberikan pengaruh nyata pada sifat kemuluran kulit jadi, hal tersebut dikarenakan kemuluran ditentukan oleh jenis dan jumlah minyak (fatliquor yang digunakan). Pada penelitian ini digunakan jenis dan jumlah fatliquor yang sama. Selain itu juga ditentukan oleh bahan baku kulit mentahnya, dengan kualitas bahan baku baik akan memberikan kemuluran yang tinggi.

Tabel 2. Analisis sidik ragam kekuatan tarik.

\begin{tabular}{lccccr}
\hline Sumber keragaman & d.b & SS & MS & $\mathrm{F}_{\text {hit }}$ & $\mathrm{F}_{\text {tbl }}$ \\
\hline Treatment & $(\mathrm{n}-1)=4$ & $\mathrm{SS}_{\mathrm{t}}=11445,30$ & $\mathrm{~S}_{\mathrm{t}}{ }^{2}=2861,32$ & 1,33 & 3,48 \\
Error & $\mathrm{n}(\mathrm{k}-1)=10$ & $\mathrm{SS}_{\mathrm{e}}=21460,01$ & $\mathrm{~S}_{\mathrm{p}}{ }^{2}=2146,00$ & & \\
\hline
\end{tabular}

Tabel 3. Analisis sidik ragam kemuluran.

\begin{tabular}{lccccr}
\hline Sumber keragaman & d.b & SS & MS & $\mathrm{F}_{\text {hit }}$ & $\mathrm{F}_{\mathrm{tbl}}$ \\
\hline Treatment & $(\mathrm{n}-1)=4$ & $\mathrm{SS}_{\mathrm{t}}=427,19$ & $\mathrm{~S}_{\mathrm{t}}{ }^{2}=106,80$ & 1,64 & 3,48 \\
Error & $\mathrm{n}(\mathrm{k}-1)=10$ & $\mathrm{SS}_{\mathrm{e}}=651,64$ & $\mathrm{~S}_{\mathrm{p}}{ }^{2}=64,16$ & & \\
\hline
\end{tabular}


Tabel 4. Analisis sidik ragam kuat sobek.

\begin{tabular}{lccccr}
\hline Sumber keragaman & $\mathrm{d} . \mathrm{b}$ & $\mathrm{SS}$ & $\mathrm{MS}$ & $\mathrm{F}_{\text {hit }}$ & $\mathrm{F}_{\text {tbl }}$ \\
\hline Treatment & $(\mathrm{n}-1)=4$ & $\mathrm{SS}_{\mathrm{t}}=1337,59$ & $\mathrm{~S}_{\mathrm{t}}{ }^{2}=334,40$ & 2,31 & 3,48 \\
Error & $\mathrm{n}(\mathrm{k}-1)=10$ & $\mathrm{SS}_{\mathrm{e}}=1449,16$ & $\mathrm{~S}_{\mathrm{p}}{ }^{2}=144,92$ & & \\
\hline
\end{tabular}

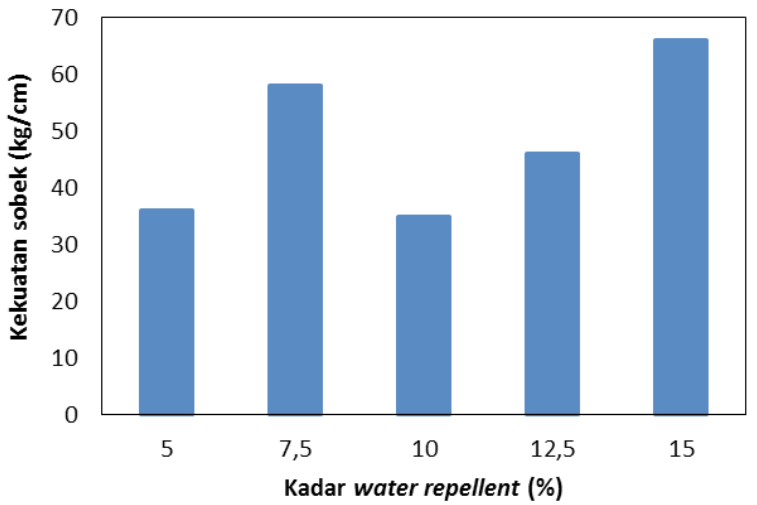

Gambar 4. Grafik kadar water repellent vs kekuatan sobek.

Hasil analisis sidik ragam kemuluran disajikan pada Tabel 3, $\mathrm{F}_{\text {htung=1,64 }}$ lebih kecil dari $\mathrm{F}_{\text {tabel }=3,48}$ ini berarti bahwa kadar water repellent tidak memberikan pengaruh nyata pada sifat kemuluran kulit jadi.

\section{Kekuatan sobek}

Hasil uji kekuatan sobek dari kulit atasan sepatu tahan dingin yang disamak dengan krom disajikan pada Gambar 4. Peningkatan kuat sobek dengan naiknya kadar water repellent yang digunakan dikarenakan water repellent dapat pula berfungsi sebagai bahan fatliquoring, sehingga naiknya bahan water repellent akan menaikan keliatan dari kulit samak yang dihasilkan.

Dari grafik terlihat bahwa tidak ada kekonsistenan dalam kekuatan sobek pada kulit hasil penelitian dengan penggunaan water repellent 7,5\%. Hal tersebut kemungkinan disebabkan tidak seragamnya mutu bahan baku kulit wet blue, sehingga kuat sobek yang dihasilkan meninggi.

Hasil analisis statistik dengan taraf kepercayaan 95\% disajikan pada Tabel 4. Analisis sidik ragam memberikan $\mathrm{F}_{\mathrm{ht}=2,31} \leq \mathrm{F}_{\mathrm{tbl}=3.48}$ menunjukan tidak ada beda nyata diantara perlakuan $(\mathrm{P} \geq 0.05)$, seperti sifat kuat tarik, kuat sobek juga sangat dipengaruhi tingkat kemasakan penyamakannya dan juga jenis bahan penyamak yang digunakan.

\section{WVP dan WVA}

Kemampuan permeabilitas uap air dan pe- nyerapan uap air kulit sangat diperlukan untuk kulit atasan sepatu untuk kenyamanan pemakai, mengingat suhu didalam sepatu akan lebih panas karena suhu dari tubuh pengguna dibandingkan suhu diluar maka uap air akan bergerak dari dalam keluar (Gulbinienẻ et al., 2003), sehingga pori bagian dalam kulit tetap harus terbuka, sedang untuk bagian kulit luar untuk mengurangi penyerapan air perlu dibuat pelapisan pada proses finishing. Hasil penelitian (Gambar 5 dan 6) menunjukkan semua perlakuan memenuhi yang disyaratkan. Namun meningkatnya kadar water repellent yang ditambahkan akan menurunkan permeabilitas uap airnya (WVP). Menurut Kanagy and Vickers (1950) penggunaan bahan untuk peningkatan ketahanan terhadap penyerapan air berakibat menurunkan sifat WVP, namun masih memenuhi persyaratan untuk kulit atasan sepatu tahan dingin, sedangkan WVA menunjukan adanya kecenderungan meningkat.

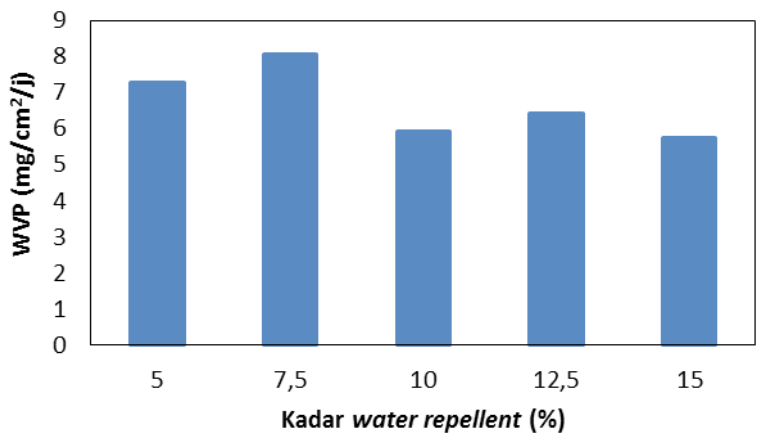

Gambar 5. Grafik kadar water repellent vs WVP.

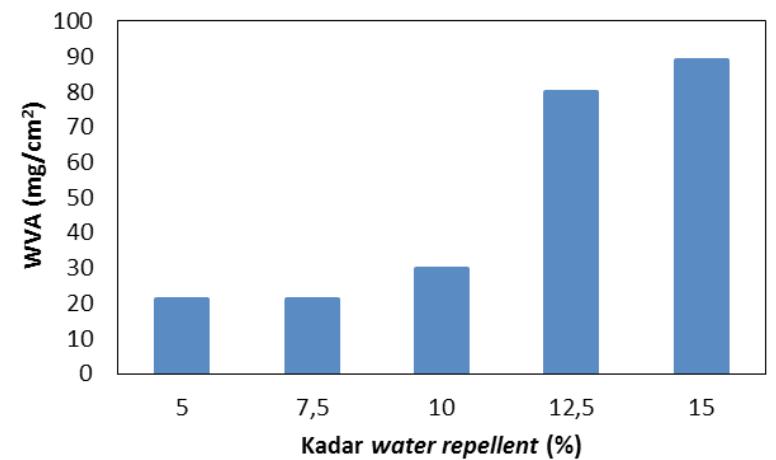

Gambar 6. Grafik kadar water repellent vs WVA. 


\section{Ketahanan bengkuk}

Hasil uji terhadap kekuatan bengkuk menunjukan bahwa semua perlakuan penambahan water repellent pada formulasi hasil penelitian memberikan hasil ketahanan bengkuk yang baik. Kulit tidak retak pada pengujian dengan lekukan 20.000 kali.

Ini berarti bahwa ketahanan bengkuk kulit samak krom dengan peminyakan menggunakan bahan Derminol SPJ sebagai fatliquor sintetik dan Derminol SPE sebagai fatliquor alami ditambah dengan water repellent $5-15 \%$ telah memberikan sifat kelemasan kulit yang baik (Prayitno et al., 2016). Sahat et al. (2010) menyatakan bahwa kulit yang disamak dengan krom mempunyai keunggulan dalam hal kemudahan proses, suhu kerut, kuat tarik, kelemasan dan softness kulit samak yang dihasilkan.

\section{Morfologi kulit}

Pengamatan penampang lintang kulit menggunakan SEM (Gambar 7) menunjukkan struktur nerf berserat cukup bersih, halus dan cerah dan meningkatnya konsentrasi water repellent menunjukan pelapisan yang bertambah merata dan halus dan lebih kompak dan pori-pori rambut tidak terlihat jelas, lapisan terlihat kompak sehingga nerf terlihat tidak berongga.

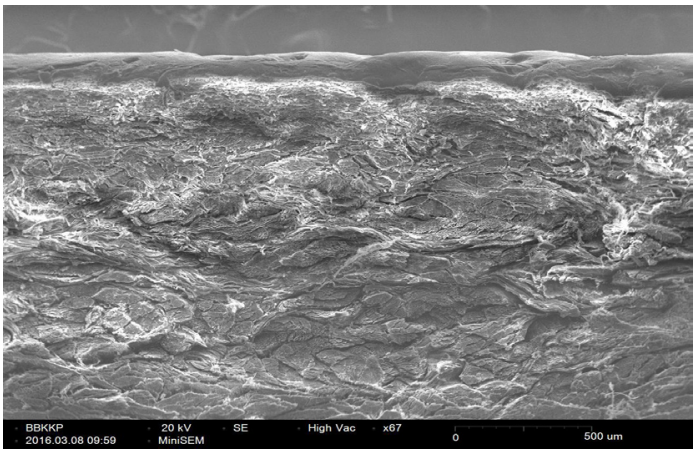

(a)

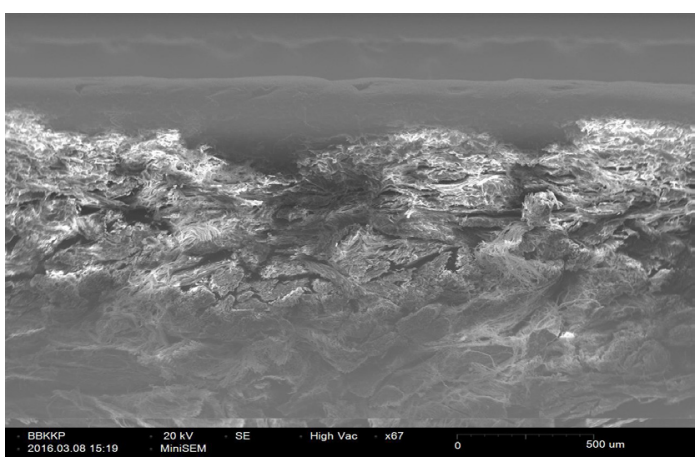

(c)

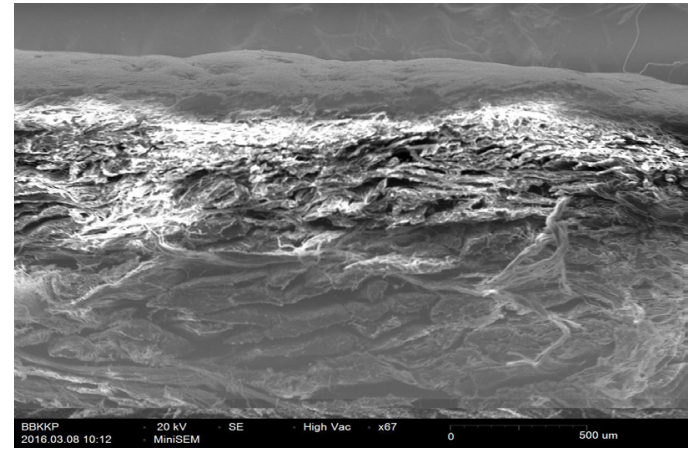

(b)

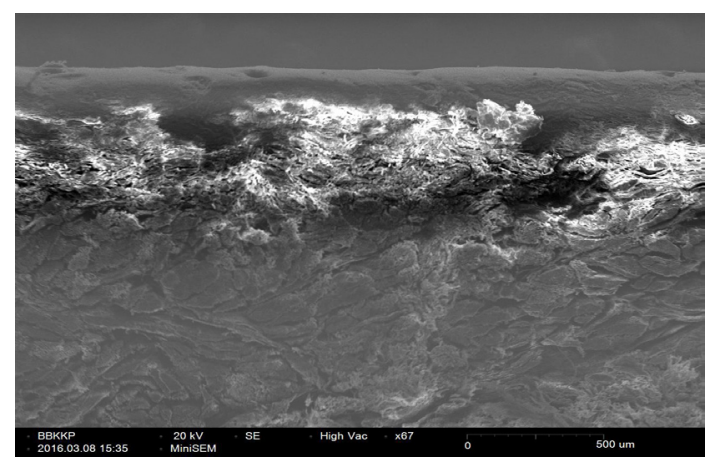

(d)

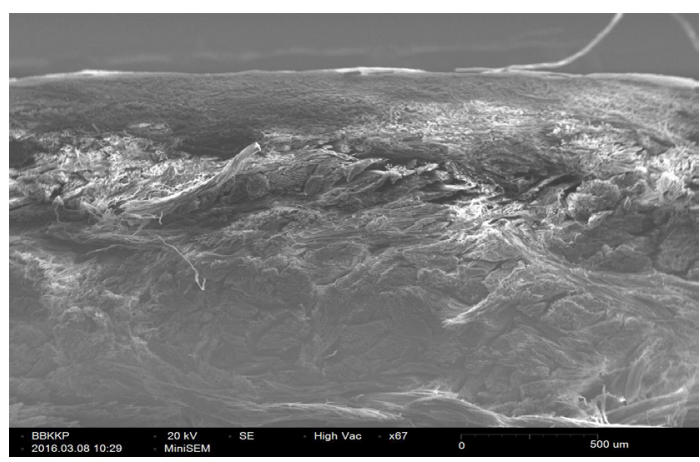

(e)

Gambar 7. Hasil uji SEM kulit dengan water repellent (a) 5\%; (b) 7,5\%; (c) 10\%; (d) 12,5\%; dan (e) $15 \%$. 
Tabel 5. Standar ISO/TR 20879:2007.

\begin{tabular}{clc}
\hline No. & \multicolumn{1}{c}{ Macam Uji } & $\begin{array}{c}\text { Syarat ISO } \\
(2007)\end{array}$ \\
\hline 1 & Penyerapan air $(\%)$ & $\leq 20$ \\
2 & Kuat tarik $(\mathrm{N} / \mathrm{mm})$ & $\geq 203,94$ \\
3 & Kemuluran, $(\%)$ & $\geq 15$ \\
4 & Kuat sobek $(\mathrm{kg} / \mathrm{cm})$ & $\geq 30,59$ \\
5 & WVP $\left(\mathrm{mg} / \mathrm{cm}^{2} / \mathrm{jam}\right)$ & $\geq 0,8$ \\
6 & WVA $\left(\mathrm{mg} / \mathrm{cm}^{2}\right)$ & $\geq 5$ \\
7 & Ketahanan bengkuk & Tidak retak \\
\hline
\end{tabular}

\section{Pemenuhan Standar ISO 20879:2007}

Dari penelitian terhadap parameter utama kulit atasan sepatu tahan dingin, terlihat bahwa penggunaan water repellent $7,5 \%$ s/d $15 \%$ sesuai perlakuan dalam penelitian memberikan hasil yang memenuhi persyaratan kulit atasan sepatu tahan dingin (Tabel 5). Hasil uji kadar air menunjukan sedikit lebih tinggi dari yang disyaratkan ISO, namun secara umum masih memenuhi syarat untuk kulit sepatu tahan dingin yaitu antara 2530\% (Jankauskaitè et al., 2012). Sedang dengan water repellent $5 \%$, kekuatan tarik belum memenuhi persyaratan.

\section{KESIMPULAN}

Kulit atasan sepatu tahan dingin dapat dibuat dengan penyamakan menggunakan bahan samak krom dengan proses finishing menggunakan water repellent jenis fluorinated acrylic polymer kemampuan penyerapan air minimum diperoleh dengan menggunakan konsentrasi water repellent $12,50 \%$ sebesar $23,80 \%$, nilai tersebut kurang dari $30 \%$ yang merupakan syarat umum maksimum kulit tahan suhu dingin. Meningkatnya konsentrasi water repellent akan meningkatkan penyerapan uap air (WVA) dan kuat tarik dan kemuluran kulit tersamak sedangkan permeabilitas akan turun. Analisis SEM menunjukan adanya pelapisan $w a-$ ter repallent pada serabut kulit.

\section{UCAPAN TERIMA KASIH}

Terima kasih kami diucapkan kepada Kepala Balai besar kulit, karet dan plastik dan Kepala Bidang Sarana Riset dan Standardisasi atas ijin menggunakan fasilitas yang ada di Balai Besar Kulit, Karet, dan Plastik sehingga penelitian ini dapat diselesaikan.

\section{DAFTAR PUSTAKA}

Covington, A. D. (2009). Tanning chemistry: The science of leather. Cambridge, UK: The Royal Society of Chemistry.

Gulbinienè, A., Jankauskaitè, V., \& Mickus, K. V. (2003). Effect of leather finishing technology on water vapour transmission. Part II: Water vapour transfer through microporous film laminated leather. Material Science, 10(3), 275-280.

ISO (International Organization for Standardization). (2007). ISO/TR 20879:2007: Footwear-performance requirement for components for footwearuppers. Jenewa, Swiss: ISO.

Jankauskaitè, V., Jiyembetova, I., Gulbinienè, A., Širvaityte, J., Beleška, K., \& Urbelis, V. (2012). Comparable evaluation of leather waterproofing behaviour upon hide quality. I: Influence of retanning and fatliqouring agents on leather structure and properties. Materials Science, 18(2), 150-157,

https://doi.org/10.5755/j01.ms.18.2.1918

Jankauskaitè, V., Gulbiniené, A., Jiyembetova, I., Širvaitytè, J., Urbelis, V., \& Mickus, K. V. (2014). Comparable evaluation of leather waterproofing behaviour upon hide quality. II. Influence of finishing on leather properties. Materials Science, 20(2), 165-170,

https://doi.org/10.5755/j01.ms.20.2.2339

Kanagy, J. R. \& Vickers, R. A. (1950). Factors affecting the water vapor permeability of leather. Journal of American Leather Chemist Association, 45, 211-242

Prayitno, P., Kasmujiastuti, E., \& Rahmawati, D. (2016). Pengaruh bahan water repellent terhadap morfologi dan sifat-sifat fisika pada pembuatan kulit atasan sepatu ramah lingkungan. Majalah Kulit, Karet, dan Plastik, 32(2), 75-84, https://doi.org/10.20543/mkkp.v32i2.922

Sarkar, K.T. (1995). Theory and practice of leather manufacture (Revised edition 1995), Madras, India: CLC Press.

Serenko, O., Nizamova, Z., Kalinin, M., Ostrovsky, Y., Polukhina, L., \& Muzafarov, A. (2014). Effect of the morphology of leather surface on the hydrophobic-hydrophilic properties. Advances in Materials Physics and Chemistry, 4, 13-19, https://doi.org/10.4236/ampc.2014.42003

Shahat, H. A., Hussein, A. I., \& Essa, M. M. (2010). Retanning agent for chrome tanned leather based on emulsion nano-particles of styrene/butyl acrylate copolymer. New York Science Journal 3(11), 13-21.

Sharphouse, J. H. (1989). Leather technician's handbook. London, UK: Leather Producer Assosiation.

Śmiechowski, K., Zarlok, J., \& Kowalska, M. (2014). The relationship between water vapour 
permeability and softness for leather produced in Poland. Journal of the Society of Leather Technologist \& Chemist, 98(6), 259-263.

Tang, K., Wang, F., Liu, J., Jia, P., \& Liu, J. (2013). Water vapor permeability of leathers by grey system theory. Reviews on Advanced Materials Science, 33, 373-382. 